\title{
Руслан Меонтійович Степанюк,
}

доктор юридичних наук, професор,

Харківський наиіональний університет внутрішніх справ, кафредра криміналістики, судової експертології

та домедичної підготовки (профресор);

https://orcid.org/0000-0002-8201-4013;

\section{Тетяна Петрівна Матюшкова,}

кандидат юридичних наук, доиент,

Харківський наиіональний університет внутрішніх справ, кафредра криміналістики, судової експертології

та домедичної підготовки (доиент);

(iD) https://orcid.org/0000-0001-7973-4581,

e-mail: t.matiushkova@gmail.com

\section{KPUMIHAAICTИKA TA FORENSIC SCIENCES: ПРОБАЕМИ ДИФЕРЕНЦІАЦӤ̈ ТА ІНТЕГРАЦІї}

Розглянуто співвідношення криміналістики та fоrensic science. Визначено, що вони $е$ відмінними моделями однієї сфери наукових знань, які збігаються за иілями та завданнями, але значно відрізняються за обсягом. Також визначено шляхи подальшого розвитку системи криміналістики та споріднених наук в Україні з огляду на світові тенденції зближення таких моделей ијеї сфери наукових знанъ, як судова наука, кримінальне розслідування та судова експертиза. Зроблено висновок про доцільність збереження природничо-технічної складової у системі криміналістики з метою запобігання ії розпаду.

Ключові слова: криміналістика, судова наука, кримінальне розслідування, судова експертиза, природа криміналістики, моделі криміналістики.

Оригінальна стаття

\section{Постановка проблеми}

У нинішніх умовах розвитку суспільства важко переоцінити практичне значення застосування досягнень науки і техніки у протидії змочинності. Багато десятиліть цю функцію виконує наука, яку в бімьшості країн, розташованих на схід від Німеччини, зокрема в Україні, називають криміналістикою. Ця наука відіграє центральну роль у сучасній системі правосуддя та має потенціал для підтримки процесу розслідування злочинів і судового переслідування змочинців і водночас захисту невинних від незаконного переслідування. Останніми роками спостерігається дедалі більша залежність кримінального розслідування від досягнень криміналістики, що обумовлено швидким розвитком науки і технологій [1].

(C) Степанюк Р. Л.,

Матюшкова Т. П., 2021 
Разом із тим, як відомо, у світі розвиваються різні моделі криміналістичної науки, серед яких у Західній Європі найбільш широко представцено так звану романську модемь під назвами "наукова поміція" і "технічна поліція", а у Великобританії, США та багатьох інших державах англосаксонської правової сім'і - "Судова наука" (forensic science, або forensics). Ураховуючи провідне місце англомовного сегменту наукової думки в сучасному світі, саме forensic science сьогодні $є$ найбільш розвиненою галуззю знань. Зазначені обставини зумовлюють потребу розгляду ії співвідношення із вітчизняною модем^ю криміналістики з метою пошуку підходів, спрямованих на інтеграцію відповідних положень в умовах глобалізації сучасного світу. В Україні це завдання видається особливо актуальним, адже країна одержала у спадок від СРСР соціалістичну модель криміналістики і помітно відстає від провідних країн світу як у технічному оснащенні, так і в розвитку теоретичних питань науки й, відповідно, нормативно-правовій регламентації та організації криміналістичної діяльності.

\section{Стан дослідження пробцеми}

Питання співвідношення криміналістики та судової науки були предметом наукових досліджень ще за радянських часів, проте розглядались однобічно і тенденційно як "критика реакційної сутності буржуазної криміналістики». У ранній пострадянський період науковці не вдавались до детального аналізу цієї проблематики, переважно розглядаючи ці галузі знань як аналогічні з поправкою на специфіку різних підходів. Проте останніми роками активізувались наукові пошуки, спрямовані на з'ясування змісту відповідних концепцій і тенденцій їх подальшого розвитку. Так, російський науковець В. Ю. Сокоц порівнював російську модель криміналістики із німецькою та англо-американською, а також розглядав окремі аспекти інтернаціоналізації та глобалізації криміналістики [2]. С. Фенивезі (C. Fenyvesi) здійснив аналіз концепцій криміналістики у континентальному та загальному праві [3]. Вітчизняній автор М. В. Шепітько розглянув концептуальні засади розвитку криміналістики та судових наук [4]. У праці Р. $\Lambda$. Степанюка та С. П. Аапти окреслено тенденції розвитку криміналістики в Україні з огляду на досвід США [5].

\section{Мета і завдання дослідження}

Метою статті є з'ясування перспектив подальшого розвитку вітчизняної моделі криміналістики під впливом інтеграційних процесів iз forensic science. Завданнями дослідження є вивчення генези становлення вітчизняної моделі криміналістики, порівняльний аналіз іiі змісту із forensic science та визначення шляхів подальшого розвитку системи криміналістики та споріднених наук в Україні з огляду на 
світові тенденції зближення різних модемей цієї сфери наукових знань.

\section{Наукова новизна досиідження}

Отримало подальший науковий розвиток дослідження співвідношення криміналістики та forensic science - відмінних моделей однієї сфери наукових знань, які збігаються за цілями та завданнями, але значно відрізняються за обсягом. Досліджено впиив інтеграційних процесів криміналістики та споріднених наук на їх зміст і вдосконамено шляхи подальшого розвитку системи криміналістики, судової науки, кримінального розслідування та судової експертизи в Україні з огляду на світові тенденції їх зближення.

\section{Виклад основного матеріалу}

У Російській імперії криміналістичні знання почали впроваджуватись наприкінці XIX - на початку XX ст. насамперед у вигляді популяризації та перекладу наукових праць Г. Гроса та Р-А. Рейса. Зокрема, А. А. Аевенстім опублікував кілька статей, спрямованих на популяризацію модемі криміналістики, запропонованої Г. Гросом [6; 7], а С. М. Трегубов організував видання праці Р-А. Рейсса з наукової техніки розслідування зцочинів (наукової поліції) [8].

Свого часу С. М. Трегубов підкреслював, що кримінальну техніку німецькі науковці відносять до науки криміналістики, але остання за

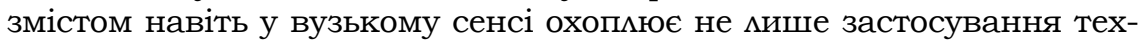
нічних знань у судовій справі, а і вивчення психологічних методів розслідування [9, с. 9]. Отже, ще за дореволюційних часів російські автори констатували, що криміналістика $є$ більш широкою галуззю знань, ніж наукова поміція.

У період існування СРСР завдяки працям Г. Ю. Манса, І. М. Якімова та їхніх послідовників усталеним у радянській державі став термін "криміналістика", а сама ця наука спочатку розвивалась як прикладна технічна дисципліна, а згодом як юридична наука. Радянські криміналісти через зрозумілі причини політичного характеру не могли здійснювати якісних порівняльних досліджень, тому обмежувались мише критикою "буржуазної" криміналістики. Переважно дослідники вважали, що терміни "судова наука", "наукова поміція", "кримінальне розслідування" тощо являють собою інші варіанти назви криміналістики. Такий підхід має певний сенс і $є$ поширеним у вітчизняній кримінамістиці донині.

В. Ю. Шепітько підкреслив, що в різних країнах криміналістику називають по-різному, а вжиття в англомовних країнах разом із терміном "forensic sciences" також і інших, зокрема "criminalistics" (як частина судових наук), "criminal investigation" (кримінальне розслідування), "criminology" (кримінологія), зумовцено відмінностями у 
широті або вузькості підходів до обсягу закономірностей, що належать до криміналістичних знань і предмета криміналістики [10, c. 143-144].

На нашу думку, це питання потребує додаткового анамізу, оскіцьки пояснення вказаної ситуації тільки суто термінологічними невідповідностями видається дещо спрощеним і призводить до певних неточностей в оцінюванні змісту вищезазначених дисциплін. До того ж указане питання має принципове значення в контексті порівняння змісту вітчизняної криміналістики зі змістом відповідних гамузей за кордоном, а головне - визначення подальших перспектив розвитку криміналістичної науки в Україні.

В. Ю. Сокол підкреслює, що в сучасний період у США криміналістика не завжди ототожнюється із forensic science, а входить до складу останньої, проте мише в частині природничо-технічних знань. водночас окрема соціогуманітарна дисципміна "criminal investigation" нагадує російську криміналістичну тактику та методику [2, с. 106]. Згаданий науковець дотримується думки, що у зв'язку з кризою російської криміналістики вона може розпастись на дві різні науки, як ангмо-американська криміналістика [2, с. 120].

На наш погляд, тут важливо звернути увагу на два аспекти. Поперше, співвідношення forensic science i criminal investigation у США чітко не визначено досі, оскільки перша фактично виникла на базі романської модемі "наукової поміції", а друга - на базі криміналістики Г. Гроса. По-друге, у багатьох країнах, які колись входими до СРСР, зокрема в Російській Федерації, криміналістика фактично вже розпалася на кімька різних наук, а саме на власне криміналістику, судову (юридичну) психологію, судову експертологію і теорію оперативно-розшукової діяльності. За такої моделі вся науково-технічна частина криміналістики у перспективі відійде до судової експертомогіï, яка поступово і стає аналогом forensic science.

Досліджуючи теорію криміналістики, Г. Галіловіц та Г. Боянік (H. Halilovic, N. Bojanic) розглянути й порівняли три модеці кримінамістики, які були прийняті, відповідно, в романських країнах, у Німеччині та Росії, а також в англосаксонських країнах. Учені відзначими, що у романських країнах, зокрема Італії, криміналістика не має статусу самостійної науки чи дисципліни та розглядається як застосування змісту і методів інших наук у галузі розслідування та судового розгляду кримінальних правопорушень. У країнах, що перебувають під впливом німецького та російського законодавства, криміналістику визнано окремою дисципліною з дослідження змочинів із певними цілями й методами дослідження. В англосаксонських країнах, зокрема в США, криміналістику розуміють у більш широкому значенні як одну із судових наук. Дві останні модемі дозволяють 
криміналістиці претендувати на статус вільної (емансипованої) дисципліни та науки. Відповідаючи на думку тих, хто вважає кримінамістику більше дисципліною, ніж наукою, оскільки вона спирається на дослідження та висновки інших наук, згадані вище науковці говорять про те, що за такого підходу навіть медицину не можна буде вважати наукою, оскільки вона також спирається на базові знання 3 інших наук [11].

Аналізуючи дослідження сучасних американських авторів, констатуємо, що в США до сьогодні поняття "criminalistics" вживається у двох значеннях - широкому та вузькому. У широкому сенсі воно застосовується як синонім "forensic science" [12, с. 99]. У вузькому ж розумінні криміналістику визначають як складову частину "forensic science" [13, с. 10]. Разом із цим щодо співвідношення forensic science i criminal investigations відзначається, що перша галузь являє собою застосування природничих і фізичних наук до права, а друга містить у собі рекомендації щодо кримінального розслідування, серед іншого і застосування forensic science [12, с. 99-100]. 3 вищевказаного можна зробити висновок про диференціацію в США наук forensic science i criminal investigations. Проте це не означає загрози розпаду континентальної криміналістики, адже до змісту останньої завжди входили два основні розділи - криміналістична техніка (природничотехнічна частина) та криміналістична тактика (переважно гуманітарна сфера), тісно пов'язані між собою.

Цікаво, що останніми роками науковці багатьох країнах світу визнають існування кризи у forensic science. Спостереження цієї проблеми навіть змусили деяких авторів поставити питання про те, чи не загрожує цій галузі вимирання [14]. У Великобританії кризу пов'язують із матеріально-технічним забезпеченням практичної діямьності [15]. Але більшість учених зосереджується на обговоренні фундаментальних проблем визначення ідентичності forensic science, iï мети, завдань та можливостей. При цьому, на думку Р. М. Моргана (R. M. Morgan), ця галузь пропонує міждисциплінарний підхід, який передбачає розуміння, що можна застосувати до питань права, водночас згаданий науковець наголошує, що forensic science має активно повернутись до наукового підходу у своїй діяльності [16]. Інші автори визнають необхідність та актуальність переосмислення структури forensic science $[17 ; 18]$. На наш погляд, заслуговує на увагу думка С. Роукс, Ф. Кріспіно й О. Рібо (С. Roux, F. Crispino, O. Ribaux), які пропонують повернутись до історичних витоків forensic science $\mathrm{i}$ вивчати змочинність та ії сліди, що призведе до розроблення цілісних моделей, забезпечить стратегію інтеграції технологій та допоможе науковцям розвивати свій потенціал для більш активної участі в поліцейській діяльності з розслідування змочинів [19]. Тобто зарахування 
до предметної сфери forensic science дослідження змочинної та слідчої діяльності, як це реалізовано у вітчизняній моделі криміналістики, вбачається одним із доцільних варіантів подолання кризи.

С. Фенівезі (C. Fenyvesi), розглянувши зміст forensic science i criminal investigation у джерелах США, дійшов висновку, що криміналістика поділяється на техніку розкриття змочинів, яка становить наукову частину forensic science, i тактику розкриття змочинів, що грунтується на соціальних наукових знаннях, які входять до criminal investigation та criminal psychology. Методика розслідування окремих видів злочинів теж належить до criminal investigation. Також згаданий автор констатує ідентичність предмета і цілей криміналістики та судової науки та поступове стирання кордонів між ними [3, с. 53-54, 57].

М. В. Шепітько, досліджуючи тенденції розвитку криміналістики та судових наук, дійшов висновку про "можливість синонімічного вживання "Криміналістики" та "Судових наук" за умови їх порівняння в конкретній ситуації, оскільки межі цих наук не збігаються" [4, с. 95].

Вищезазначені підходи, на нашу думку, різнобічно характеризують співвідношення підходів до розуміння цілей, змісту і тенденцій розвитку криміналістичної науки в континентальній Європі та країнах загального права. Але варто зауважити, що соціалістична модель криміналістики, представлена серед іншого і в Україні, дещо відрізняється від ії германської моделі. При цьому головна відмінність помягає в інтерпретації цієї науки як правової (юридичної). Ця концепція стала домінуючою в СРСР в середині XX століття і, на нашу думку, негативно вплинула на подальший розвиток досліджуваної галузі знань. У результаті цього в сучасний період порівняльний анаАіз змісту вітчизняної криміналістики зі змістом споріднених дисциплін США дає підстави для такого висновку: "Уявлення про кримінамістику як науку суто юридичної природи, що залишилося в спадок від радянських часів, фактично призвело до виродження природничо-технічного напряму криміналістичних досліджень і перетворило сучасну українську криміналістику на гуманітарну науку про кримінальне розслідування, аналогом якої можна вважати дисцип-

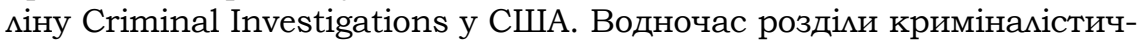
ної техніки та судової експертизи належно не розвиваються через відсутність чіткого розуміння обсягу та місця відповідних знань у наявній системі наук" [5, с. 294]. Таку ситуацію не можна визнати прийнятною. Фактично ми маємо визнати, що модель криміналістики, запропонована свого часу Г. Гросом, у нашій країні продовжує існувати майже без змін. Тобто якщо у світі за понад сто років ця галузь знань значно розвинулась, то у нас залишається на рівні "науки для слідчого", хоча обсяг процесуальних повноважень слідчого, а отже, і його роль у діяльності зі встановлення істини у кримінальному провадженні 
відтоді радикально знизились. Але головна проблема в тому, що принципова відмінність між криміналістикою Г. Гроса і судовою наукою полягає в обсязі їх юридичних і природничо-технічних складових. Якщо у першій моделі домінують знання соціально-гуманітарного характеру (тактичні та методичні аспекти слідчої діяльності), то до другої їх у здебільшого не включають узагалі, акцентуючи увагу виключно на природничо-технічних розділах.

Видається, що інтеграція тактичних і технічних криміналістичних засобів та методів протидії є цілком прийнятною і не просто значно збагачує арсенал досліджуваної галузі знань, а і зумовлює іï існування як самостійної науки в цілому. Саме такий підхід дає змогу відносити криміналістику не просто до одного з багатьох розділів судової науки, а виділяти як окрему найбільш об'ємну науку, яка інтегрує всі інші судові дисципліни.

ДАя України, як і для більшості інших країн колишнього соціалістичного табору, це питання є особливо актуальним. Пояснюється це тим, що криза криміналістики в нашій державі виникла не стільки через сумніви в науковій основі більшості технічних ії розділів, як у судових науках, стільки через глухий кут у розвитку криміналістичної техніки в цілому та відсутність перспектив розвитку цілих новітніх галузей криміналістичних знань.

Наприклад, у вітчизняній системі наук узагалі не було сформовано таких галузей, як судова біологія, судова хімія, судові IT-технології тощо. Здавалося б, що саме криміналістика мала б містити відповідні розділи. Але цього не відбулось, унаслідок чого скламася ситуація, коли найвагоміші в правозастосовній практиці сфери судово-експертних досліджень не мають належного теоретичного обгрунтування, відсутні в освітньому процесі та застосовуються виключно у практичній площині. Українська система криміналістичної техніки досі залишається на рівні середини минулого століття, тих часів, коли криміналістику перетворили на виключно юридичну науку та фактично закрили шлях до неї фахівцям із природничо-технічних галузей. Видається, що проблема потребує термінового вирішення, з огляду на те, що в сучасний період в Україні визнаною $\epsilon$ мультидисциплінарність криміналістики як науки синтетичної природи. Ураховуючи це, вважаємо нагальним удосконалити систему криміналістичної техніки, віднісши до неї всі новітні галузі, визнані у світі, зокрема ті, що належать до дисциплін forensic science, але в Україні не мають статусу окремої науки. Це криміналістичний ДНКаналіз, IT-криміналістика, дослідження наркотичних засобів, судова поліграфологія тощо.

Окремої уваги заслуговує питання щодо виокремлення з криміналістики такої галузі, як теорія судової експертизи (судова експертологія). 
Ця тенденція, яка спостерігається в окремих пострадянських країнах, зокрема в Україні, як ми вважаємо, негативно впливає на подальший розвиток криміналістичної науки, оскільки зовсім не відповідає завданням іiі інтеграції із судовою наукою. На нашу думку, якщо визнати судову експертологію окремою наукою, то саме вона претендуватиме на роль вітчизняної forensic science. У цьому разі в криміналістиці залишиться мише ії частина, присвячена питанням тактики та методики розслідування окремих видів кримінальних правопорушень, отже, знову постане питання про доцільність існування такої науки взагалі, адже ця проблематика може бути інтегрована в науку кримінального процесу як ії спеціальна частина. Не кажучи про інші негативні наслідки такого варіанту розвитку подій, зауважимо, що він суперечить уявленням про сутність і зміст криміналістики не $и$ в Україні, а й у всьому світі. Зважаючи на вищерозглянуті iii моделі, неправильно прирівнювати криміналістику до criminal investigation, а доцільно говорити або про германську модель кримінамістики, яка фактично являє собою "criminal investigation + forensic science", або про модель окремих "forensic science" та "criminal investigation", де криміналістика є частиною forensic science, asе не criminal investigation. Здається очевидним, що вітчизняна традиція передбачає розвиток першої моделі, тому теорія судової експертизи та ії окремі галузі, які не мають розвитку в межах основних (материнських) наук, мають залишатись складовими частинами криміналістики. Це відповідатиме світовим тенденціям взаємного впливу криміналістики та судової науки, межі між якими стають дедалі менш чіткими, що поступово має обумовити їх зближення насамперед через взаємовплив щодо визначення предмета і внутрішньої будови.

\section{Висновки}

Криміналістика та forensic science являють собою дещо відмінні між собою моделі однієї сфери наукових знань. Вони збігаються за цілями та завданнями, але значно відрізняються за обсягом. До forensic science узвичаєно відносити всі наукові галузі, пристосовані

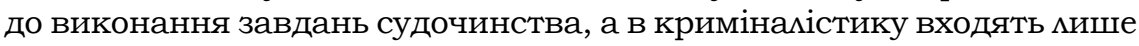
ті з них, які не мають статусу окремої науки. Водночас у вітчизняній моделі криміналістики представлено питання правового характеру (криміналістичну тактику та методику), що робить їі наукою подвійної (синтетичної) природи, на відміну від forensic science, природа якої є природничо-технічною.

Інтеграційні процеси, які спостерігаються у розвитку криміналістики та forensic science, поступово призводять до зближення цих наук за змістом. Ураховуючи вказане, в Україні недоцільно здійснювати подальші кроки щодо розпаду криміналістики шляхом виокремлення судової експертології в окрему науку, інакше станеться повне 
вихолощення природничо-технічної складової криміналістики, що може мати наслідком зникнення цієї науки взагалі. Питання щодо вдосконалення системи криміналістики, як і forensic science, з урахуванням взаємного впливу їхніх досягнень, є перспективними напрямами подальших наукових пошуків.

Cписок бібліографічних посимань: 1. Bouzin J. T., Sauzier G., Lewis S. W. Forensic science in Seychelles: An example of a microjurisdiction forensic delivery system. Forensic Science International: Synergy. 2021. Vol. 3. DOI: https://doi.org/10.1016/j.fsisyn.2021.100139. 2. Coком В. Ю. Кризис отечественной криминалистики : монография. Краснодар, 2017. 332 с. 3. Fenyvesi C. The continental and common-law conceptions of criminalistics. US-China law Review. 2017. Vol. 14. Pp. 46-57. DOI: https://doi.org/10.17265/1548-6605/2017.01.004. 4. Шепітько М. В. Концептуальні засади розвитку криміналістики та судових наук. Архів кримінологї та судових наук. 2020. № 1. С. 89-97. 5. Степанюк Р. А., Мапта С. П. Можливості розвитку криміналістичної науки в Україні 3 огляду на досвід США. Вісник Аугансъкого державного університету вну mpiuнix справ. 2018. № 3. С. 289-297. 6. Мевенстим А. А. Доктор Ганс Гросс и его проект улучшения следственной части. Журнал юридического обиества при Санкт-Петербургском университете. 1896. Кн. 3. С. 47-66. 7. А. $\Lambda$. Что такое криминалистика? Журнал министерства юстииии. 1900. № 9. С. 114-125. 8. Рейсс Р. А. Научная техника расследования преступлений / сост. под ред. С. Н. Трегубова, ст. юрисконсульта М-ва юст. и проф. уголов. права Александр. воен.-юрид. акад. и Уч-ща правоведения. СПб. : Сенатская тип., 1912. 178 с. 9. Трегубов С. Н. Основы уголовной техники. Научно-технические приемы расследования преступлений: практическое руководство для судебных деятелей. М. : Право, 1915. 334 с. 10. Шепитько В. Криминалистика в системе наук и её роль в гмобальном мире. Криміналістика та судова експертиза: наука, навчання, практика. 2014. Т. 1. С. 143-153. 11. Halilovic H., Bojanic N. Criminalistics-Scientia Sui Generis-Arguments Pro et Contra // U.S. Department of Justice : сайт. https://www.ojp.gov/ncjrs/virtuallibrary/abstracts/criminalistics-scientia-sui-generis-arguments-pro-etcontra (дата звернення: 18.07.2021). 12. Birzer M. L., Roberson C. Introduction to Criminal Investigation. Boca Raton : CRC Press, Taylor \& Francis Group, 2012. 372 p. 13. Lyman M. D. Criminal investigation: the art and the science. 6th ed. Hoboken : Published by Prentice Hall, 2011. 668 p. 14. San Pietro D., Kammrath B. W., De Forest P. R. Is forensic science in danger of extinction? Science \& Justice. 2019. Vol. 59, Iss. 2. Pp. 199-202. 15. Forensic science in England \& Wales, a commentary Gillian Tully forensic science Regulator, 5 St Philip's Place, Colmore Row, Birmingham, B3 2PW, United Kingdom. 16. Morgan R. M. Conceptualising forensic science and forensic reconstruction. Part I: A conceptual model. Science and Justice. 2017. No. 57. Pp. 455-459. 17. Roux C., Talbot-Wright B., 
Robertson J., Crispino F., Ribeaux O. The end of the (forensic science) world as we know it? The example of trace evidence. Philosophical Transactions of the Royal Society B. 2015. No. 370. DOI: https://doi.org/10.1098/ rstb.2014.0260. 18. Kinder J. D., Pirée H. The future of the forensic science providers - Time to re-think our structures? Forensic Science International. 2020. No. 316. DOI: https://doi.org/10.1016/j.forsciint.2020.110471. 19. Roux C., Crispino F., Ribaux O. From forensics to forensic science. Current Issues in Criminal Justice. 2012. No. 24 (1). Pp. 7-24.

Надійщла до редколегіï 22.07.2021

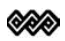

\section{Stepaniuk R. L., Matiushkova T. P. Criminalistics and Forensic Sciences: Problems of Differentiation and Integration}

The authors have clarified perspectives for further development of criminalistics in Ukraine under the influence of integration processes of this science from Forensic Science. The genesis of the national model of criminalistics has been briefly studied; a comparative analysis of its content with Forensic Science has been accomplished; and the ways of further development of the system of criminalistics and related sciences in Ukraine have been defined considering the global tendencies of convergence of different models of this field of scientific knowledge. It has been emphasized that the use of the terms of "Criminalistics", "Forensic Sciences" and "Criminal Investigation" is explained not just by the specifics of terminology in different countries, but primarily due to differences in defining the nature and internal content of these disciplines. According to the authors, the integration of tactical and technical criminalistics tools and methods of combating crime is quite acceptable and not only significantly enriches the arsenal of criminalistics, but determines its existence as an independent science. Such an approach allows us to consider criminalistics not just as one of the many sections of Forensic Sciences, but to single out it as one of the most comprehensive sciences that integrates all other forensic disciplines. The domestic model of criminalistics, in contrast to Forensic Science, represents the issues of a legal nature (criminalistics tactics and methodology), which makes it a science of dual (synthetic) nature. The integration processes observed in the development of criminalistics and Forensic Science are gradually leading to the convergence of these sciences in content. Given this, it is impractical to take further steps to disintegrate criminalistics in Ukraine by separating forensic expertise into a separate science. Otherwise, there will be a complete depletion of the natural and technical component of criminalistics, which may result in the disappearance of this science in general.

Key words: criminalistics, forensic science, criminal proceedings, forensic examination, nature of criminalistics, models of criminalistics. 